\title{
Marie Curie (1867-1934): Famed female face of Science
}

\author{
Patricia Sims $\underline{\text { Poole }}{ }^{1}$, MD, Siang Yong $\underline{\operatorname{Tan}^{2}}, \mathrm{MD}, \mathrm{JD}$
}

Nothing in life is to be feared. It is only to be understood. - Marie Skoldovska-Curie.

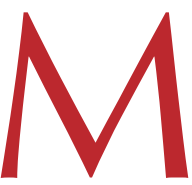
arie Curie, a pioneer scientist, accomplished a series of firsts throughout her committed life. She was the first Nobel laureate to win two separate Nobel prizes, the first woman in Europe to complete a doctorate, and the first and only woman to be laid to rest under the famous dome of the Pantheon for her own accomplishments. Madame Curie is the famed female face of science, her name synonymous with the international unit of radioactivity.

EDUCATION AND LOVE Born Marie Skoldovska in 1867, the Polish "Marya" was the youngest of five children born to two teachers who instilled in her a deep respect for education. Her mother, Madame Skoldovska, was frail and afflicted with tuberculosis when she was pregnant with Marya, and died not long thereafter. The family environment, with evening readings in literature and poetry, was scholarly if not warm, and it influenced her intellectual growth. She developed an early love of the sciences, preferring them to studies in literature. Although Marie disliked her school's director, she easily excelled and topped her class.

The late 1800s saw the Russian reprisal in Poland, and Marie met with continual barriers to her intellectual advancement, being denied a classic university education due to her gender. However, with perseverance and determination, she managed to attend the illegal Floating University in Warsaw and worked as a private tutor while saving money to join her older sister in Paris. Marie's dream of studying at the Sorbonne in France was realised in the autumn of 1891. Still, her path was not an easy one. Strapped for money and handicapped by poor preparation in the physical sciences, she spent many long hours absorbed in her studies and part-time jobs, but eventually graduated at the top of her class with a degree in physics and then in mathematics.

A woman not usually given to romantic notions, Marie's drive for education in Paris nonetheless led her to love. She was introduced to a fellow scientist, Pierre Curie, who had a laboratory at the Municipal School of Industrial Physics and Chemistry.

Pierre was a physicist in Europe and well known for his work on crystals and electronics. Previously uninterested in other women, he was attracted to and finally fell in love with the talented Marie, who initially rebuffed his romantic gestures, even though she was struck by Pierre's "grave and gentle expression... as well as a certain abandon in his attitude, suggesting the dreamer absorbed in his reflection." Pursued even when she returned to Poland, Marie eventually accepted his proposal and the couple was married in 1895.

POLONIUM, RADIUM AND TRAGEDY Marie's doctoral thesis dealt with the unusual element, uranium, discovered by Henri Becquerel and announced to the Academy of Sciences in Paris in 1896. The atomic nucleus

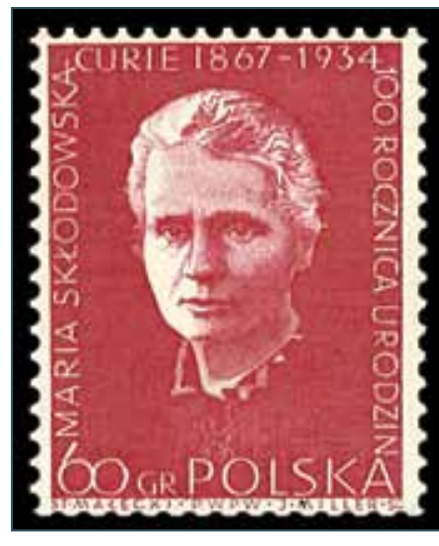
of a radioactive element such as uranium is intrinsically unstable, the forces between the protons and neutrons being insufficient to hold the nucleus together. The atom would progressively decay, breaking down into more stable compounds, and in the process, emit radiation. Uranium's radioactive 'rays', with the exception of thorium's, were not evident in any of the other 80 elements known at that time. Together with Pierre, Marie was able to identify two additional new elements extracted from the brown-black mineral ore called pitchblende, a major source of uranium. The first was named polonium in honour of her beloved country of birth, and the second, radium. Polonium turned out to be too unstable an element to research, so they turned their energies to radium. The couple's foremost task was to extract the rare radium from pitchblende after the uranium had been harvested. It was a tedious task. After four years, they managed to amass an amount of radium barely covering the tip of a teaspoon - about 0.1 gram.

The discoveries, which formed part of her doctoral thesis, were published in December 1898, and won the couple the Nobel Prize in Physics in 1903. But tragedy was to strike three short years later, after the birth of their second daughter. On April 19, 1906, after leaving his publishers, Pierre Curie absent-mindedly walked into the path of an oncoming horse-drawn wagon and was killed instantly. Crushed by the news of Pierre's death, Marie took refuge in her husband's inspiration and love for their work, and sought to establish a research institute in his memory. In 1914, the Radium Institute was established with joint funds

${ }^{1}$ Research carried out during transitional internship at Hawaii Residency Program, Inc, ${ }^{2}$ Emeritus Professor of Medicine, University of Hawaii Correspondence: Prof Tan Siang Yong, 2230 Liliha Street, Suite 104, Honolulu, HI 96817, USA. siang@hawaii.edu 
from the University of Paris and the Pasteur Foundation. It was set up as a medical research laboratory devoted to the study of radioactivity, headed by Marie herself, but its opening had to be delayed until after the war was over. The Institute became the focal point of the rest of her life.

RADIOLOGY IN WAR Paris saw the start of World War I in 1914, and Marie turned her efforts to supporting France's military by using X-rays that enabled doctors to see bullets, shrapnel and broken bones. Appointed Director of the Red Cross Radiology Service, Marie set up France's first military radiology centres, consisting of 20 vehicles that were equipped with mobile X-ray apparatuses, known as 'petites Curies', to help the wounded on the battle-front. She not only learned how to drive a car, but spent her free time studying anatomy and auto mechanics, intending to operate the 'little Curies' herself. Marie also began to establish radiation therapy services within the military. She personally purified radium and collected the colourless radioactive gas, radon, in thin glass tubes for use in both civilian and military hospitals to destroy diseased tissues. These war-time experiences were published in her book, Radiology in War.

THE LEGACY Marie Curie literally ushered in the atomic age. Although radiation therapy may be considered her most notable medical contribution, it is her basic research into radioactive elements that won her Nobel Prizes in Physics and Chemistry. Additionally, she had a positive impact on the education of women. Although her consuming research had required her to give up her teaching job at the Sevres school for women teachers-in-training, she continued to support women's education and her staff always included some Polish and women researchers. This devotion paid off as Marie's work caught the interest of an American woman, who started the Marie Curie Radium Campaign. Despite Marie's discomfort with travelling and being away from her family and work, she took the opportunity to travel to the United States to raise money for further research on radium. She made two trips, and with the help of her two daughters, was able to raise enough money to help fund the Warsaw Radium Institute, founded in 1925 in Poland. In her later years, she served on the Commission on Intellectual Cooperation for the League of Nations to establish an international bibliography of scientific papers, as well as to develop standards for international scientific scholarships.

Pierre and Marie's work was in its purest form - enjoyment. Marie said, "A scientist in his laboratory is not a mere technician: he is also a child confronting natural phenomena that impress him as though they were fairy tales." She believed that all scientists should devote their lives purely to scientific research, ignoring personal and social matters. She refused to patent the process used to isolate radium in order to allow the scientific community open access to an exciting and fast-moving field. In her own family, her oldest daughter, Irène Joliot-Curie worked at the Radium Institute, and there, together with her husband Frédéric Joliot, discovered artificial radioactivity when they determined that aluminum produced neutrons when bombarded with alpha rays. Only a few months after her mother's death, Irene was awarded the Nobel Prize for Chemistry in 1935 for this work. Marie's youngest daughter, Eve Curie, became a published writer, known for her biography, Madame Curie. In it, she attributes to Albert Einstein the observation that "Marie Curie is, of all celebrated beings, the one whose fame has not corrupted."

In 1934, Marie Curie began to experience weakness, dizziness and fatigue, and died on the morning of July 4 from aplastic anaemia caused by a lifetime exposure to ionising radiation. The brilliant scientist was largely unaware of its adverse effects, and much of her work was done in a simple, unprotected wooden shed.

\section{BIBLIOGRAPHY}

- Coursey B. Marie Curie and the NBS Radium Standards. The National Institute of Standards and Technology [online]. Available at: www.physics. nist.gov/Genlnt/Curie/main.html. Accessed December 16, 2007.

- Marie Curie. In: Nobel Lectures, Physics 1901-1921. Amsterdam: Elsevier Publishing Company, 1967.

- Marie Curie. In: Wikipedia, the free encyclopedia. Wikimedia Foundation, Inc [online]. Available at: en.wikipedia.org/w/index.php?title=Marie Curie\&oldid=176839004. Accessed December 192007.

- Fröman N. Marie and Pierre Curie and the Discovery of Polonium and Radium. Nobelprize.org. December 1, 1996. Nobel Foundation [online]. Available at: nobelprize.org/nobel_prizes/physics/articles/curie/index. html. Accessed October 15, 2007.

- Pasachoff N. Marie Curie and the Science of Radioactivity. American Institute of Physics. 2002 [online]. Available at: www.aip.org/history/curie/ contents.htm. Accessed October 15, 2007.

- Zbigniew Z. Maria Sklodowska-Curie, 1867-1934. Polish-origin Nobel Prize Laureates. April 10, 2007 [online]. Available at: www.pl-nobel.prv. pl. Accessed October 15, 2007. 